\title{
Mold Surface Contamination during Polymer Processing
}

Zdenek Dvorak $^{1,2}$, Eva Hnatkova ${ }^{1,2}$, Michal Sedlacik ${ }^{1,2}$

${ }^{1}$ Department of Production Engineering, Faculty of Technology, Tomas Bata University in Zlin, Vavreckova 275 , 76001 Zlin, Czech Republic

${ }^{2}$ Centre of Polymer Systems, University Institute, Tomas Bata University in Zlin, Trida T. Bati 5678, 76001 Zlin, Czech Republic. E-mail: zdvorak@ft.utb.cz

The aim of this work is concerned with a problematic adhesion of polymer materials on the surface of processing tools. Such phenomenon plays especially an important role in production of rubber components which creates an additional and considerable costs associated with mold cleaning. However, the origin of contamination is still not fully known yet. From production point of view, the attention should be paid to three fundamental aspects: processed material, material of processing tool, and processing conditions. This study describes the results of mold's surface contamination during processing a rubber compound in terms of material and surface treatment. A method of spectral analysis in terms of FTIR was used for proper examination of this problem.

Keywords: Rubber; Fouling; Contamination; Mold Surface; FTIR

\section{Acknowledgment}

This work was supported by the Ministry of Education, Youth, and Sports of the Czech Republic - Program NPU I (LO1504). This study was also supported by the internal grant of TBU in Zlin IGA/FT/2016/002 funded from the resources of the specific university research. The authors would like also to thank Barbora Hanulikova for her help with FTIR analysis.

\section{References}

[1] PREKOP, Š. (1998). Gumárska technológia I. Žilina: Žilinská univerzita.

[2] ŠPAČEK, J. (1987). Technologie gumárenská a plastikářská. Brno: VUT.

[3] DUCHÁČEK, V., HRDLIČKA Z. (2009). Gumárenské suroviny a jejich zpracování, Praha: VŠCHT v Praze.

[4] FORREST, M. J. (2001). Rubber Analysis: Polymers, Compounds and Products, Vol. 139, iSmithers Rapra Publishing.

[5] HORNSBY, P. R., SINGH, I., DALEY, J. R., FIRTH, J. (2006). Mould fouling of elastomers during injection moulding. Plastics, rubber and composites, vol. 35(8), pp. 331-339.

[6] HAVLÍČKOVÁ, K. (2014). Methods of Mold Cleaning from Vulcanized Residues. Master thesis, Zlín: UTB in Zlín.

[7] DAVIS, G. D. (1993). Contamination of surfaces: origin, detection and effect on adhesion. Surface and interface analysis, 20(5), pp. 368-372.

[8] HÁBA, J. (2015). Contamination of tool steels during rubber vulcanization. Master thesis, University of Tomas Bata in Zlin.

[9] ČERVINKA, M. (2015). Contamination and surface protection of molds made of aluminum alloys. Master thesis, Zlín: UTB in Zlín.

[10]DVOŘÁK, Z. (2011). Zpracovatelské procesy gumárenské: pro konstrukční směry. Zlín: UTB ve Zlíně.

[11]INSTITUT GUMÁRENSKÉ TECHNOLOGIE A TESTOVÁNí ZLÍN (1996). Problematika špinění forem: Studie o př́ćinách vzniku a možnostech jejího snižení. Zlin.

[12]BUKHINA, M. F., MOROZOV, Y. L., Van de VEN, P. M., NOORDEMEER, J. W. M. (2003). Mould fouling of EPDM rubber compounds. Kautschuk Gummi Kunststoffe, 56(4), pp. 172-183. 